\title{
Original Paper \\ Tree species richness and composition in a fragmented landscape of the Brazilian lowland Atlantic Forest
}

\author{
Solange de Vasconcellos Albuquerque Pessoa ${ }^{1,2,4}$ \& Dorothy Sue Dunn de Araujo ${ }^{1,3}$
}

\begin{abstract}
Tropical forests are one of the most important ecosystems and loss of biological diversity in these is a major concern. We studied seven forest remnants on the coast of Rio de Janeiro, southeastern Brazil, three medium-sized (24-63 ha) and four small (5-11 ha), to assess the influence of size, degree of disturbance and isolation on composition and diversity of the tree layer. A total of 443 species in 60 families and 185 genera were recorded, with Myrtaceae, Lauraceae and Fabaceae being the most species-rich families. The results showed areas of high $\alpha$-diversity $(\alpha=34.86-75.69)$ and a slightly greater decline of similarity with distance between the study areas. Remnant size not explained the variation in the species composition and we found correlation between the level of disturbance and the floristic composition. The remnants had low floristic similarity, strongly influenced by the degree of disturbance. Results suggest that disturbance influences composition and diversity and confirm the importance of including both medium-sized and small remnants in the conservation of tropical forest diversity.
\end{abstract}

Key words: coastal lowlands, biodiversity, forest remnants, tropical forest.

\section{Resumo}

As florestas tropicais constituem um dos mais importantes ecossistemas mundiais e a perda da diversidade biológica é uma das grandes preocupações. Para avaliar a influência do tamanho, grau de perturbação e isolamento dos remanescentes florestais na composição e diversidade do estrato arbóreo, nós estudamos sete remanescentes florestais situados na costa do Rio de Janeiro, sudeste do Brasil, três de tamanho médio (24-63 ha) e quatro pequenos (5-11 ha). Um total de 443 espécies em 60 famílias e 185 gêneros foi registrado, sendo Myrtaceae, Lauraceae e Fabaceae as famílias mais ricas em espécies. Os resultados mostraram áreas de alta diversidade $\alpha(\alpha=34.86-75.69)$ e um declínio ligeiramente maior de similaridade com a distância entre as áreas estudadas. O tamanho do remanescente não explicou a variação na composição de espécies e nós encontramos correlação entre o nível de perturbação e a composição florística. Os remanescentes apresentaram baixa similaridade florística, fortemente influenciada pelo grau de perturbação. A relação entre riqueza de espécies e tamanho da área e isolamento não foi significativa. Os resultados sugerem que a perturbação influencia, de forma considerável, a composição e diversidade e confirma a importância da inclusão de remanescentes de tamanho médio e pequeno para a conservação da diversidade de florestas tropicais.

Palavras-chave: planície costeira, biodiversidade, remanescentes florestais, floresta tropical.

\section{Introduction}

Habitat loss and fragmentation are two major factors responsible for the decline of biological populations (Fahrig 2003). Some species and populations are dependent on the existence and extent of specific habitats, and the loss of these habitats can directly or indirectly impact such species (Dale et al. 1998). The perception of a species-area effect represents one of the oldest concepts in ecology (Arrhenius 1921) being proposed in a comprehensive model in the Theory of Island Biogeography (MacArthur \& Wilson 1967). Among the factors recognized the best known are: (1) that large areas can support more species than do small one; (2) that areas with high

\footnotetext{
${ }^{1}$ Instituto de Pesquisas Jardim Botânico do Rio de Janeiro, R. Pacheco Leão 915, 22460-030, Rio de Janeiro, RJ, Brazil

${ }^{2}$ ORCID: <https://orcid.org/0000-0003-4596-2302>

3 ORCID: <https://orcid.org/0000-0001-6661-3035>

${ }^{4}$ Author for correspondence: spessoa@jbrj.gov.br
} 
habitat diversity will support more species than those with low habitat diversity and (3) that more distant areas can support fewer species than nearest areas. Relationship between size, isolation and species diversity, both theoretical (Haila 2002) and empirical (Santos et al. 2008; Arroyo-Rodríguez et al. 2009; Galanes \& Thomlinson 2009), have been found in response to changes in landscape patterns.

Few areas covered by tropical forests have escaped some form of anthropogenic impact and the replacement of huge areas of forests by other ecosystems has created isolated patches of discontinuous forest usually small in area, that expose the biota to habitats that vary greatly from those of the original ecosystem. Populations of forest species shrink, dispersal patterns disappear and areas once located within the forest suffer the influence of conditions peculiar to forest edges (Laurance et al. 2011; Santos et al. 2012). Persistent manmade disturbances are a constant threat to biodiversity (Lôbo et al. 2011) as are changes in microclimate linked to these events, (greater wind exposure, higher light intensity and lower atmospheric humidity). These affect the density and distribution of both plant and animal species as well as interactions among species (Murcia 1995). In small fragments the intensity and magnitude of edge-effects lead to detrimental consequences for the functioning of the remaining species assemblages, and for long-term persistence of some species groups (Santos et al. 2008; Tabarelli $\&$ Lopes 2008). Therefore, changes brought about by fragmentation greatly influence the structure, floristic composition and species richness of these areas.

Most tropical-forest tree species are rare or unique and for many tropical forests the repeated disappearance of these species across landscapes may result in regional extinctions (Silva \& Tabarelli 2000). Over the last few decades the number of studies addressing loss of both tree species richness and diversity in fragmented tropical rainforests has been growing (Pereira et al. 2007; Oliveira et al. 2008; Laurance et al. 2011). This is the case of tropical lowland forests that have been severely fragmented for centuries (Joly et al. 2014). In the Brazilian Atlantic Forest, the landscape has been modified by various activities for over two centuries. In recent decades, forests that lie at low elevations on the so-called "sea of hills" in the central part of Rio de Janeiro state have been devastated mainly by cattle-raising activities (Carvalho et al. 2006; Pessoa \& Araujo 2014).
Human disturbance (e.g., selective logging, grazing, firewood extraction) is an important force capable to regulate the regeneration dynamics, structure, floristic composition and diversity of tropical forests (Dalling et al. 1998; Pereira et al. 2007; Arroyo-Rodríguez et al. 2013). Decreased populations or even extinction of species can be observed with effects persisting for long periods (Oliveira et al. 2008). In fact, disturbance leads to community reorganization directed by spatial and temporal heterogeneity, changes in the availability of resources and species replacements (Galanes \& Thomlinson 2009; Lôbo et al. 2011).

Here we aimed at describing the tree diversity in a highly fragmented landscape and to analyze the composition and similarity of plant assemblages between remnants based on fragment size, isolation and disturbance status. Given that only a few of the original tree species are able to survive in forest remnants; isolation, that is, the distance between patches, usually leads to more restricted dispersion of organisms resulting in functional isolation of many populations. Based on the species-area relationship (Silva \& Tabarelli 2000; Awade \& Metzger 2008), we expect lower species richness in the more isolated remnants, greater species richness in the larger remnants and higher diversity in lessdisturbed remnants.

\section{Material and Methods}

Study site

This study was carried out in seven remnants of dense, moist, lowland tropical forest (Veloso et al. 1991) lying on low hills, with areas that vary from 5 to 63 ha, located in the São João river watershed, in Silva Jardim and Casemiro de Abreu municipalities, Rio de Janeiro state, Brazil $\left(22^{\circ} 24^{\prime}-22^{\circ} 30^{\prime} \mathrm{S}\right.$; $42^{\circ} 05^{\prime}-42^{\circ} 22^{\prime} \mathrm{W}$ ) (Fig.1). Two remnants (F4 and F5) are located in the Poço das Antas Biological Reserve, a federal conservation unit, and the other five are on private land (F1 - Santo Antonio do Maratuã; F2 and F6 - Santa Helena; F3 - Carioca; F7 - Trinta). The distance from one remnant to any one of the other remnants varies from 65 meters to 22.65 kilometers. Degree of isolation also varies, that is, some are grouped together while others are more widely scattered (maximum isolation distance 262 m). Remnants F4, F5, F2 and F6 have a narrow forest connection while the others are totally or partiatly surrounded by pasture. Remnants F4 and F5 are fairly well conserved, with no signs of timber extraction or other disturbance until the construction of the Juturnaíba Dam (Pessoa \& Oliveira 2006). 
The other remnants are undergoing secondary succession following disturbance. Remnants $\mathrm{F} 1, \mathrm{~F} 2$ and F6 are at an intermediate stage of deforestation; 20-40 yr after cessation of selective logged activities, signs of the felling of large trees can still be spotted. Remnants F3 and F7 are the most highly disturbed, with many lianas, more tree stumps, a less dense understorey and a more open canopy. Exploitation ceased 10-15 years before this study began. The grassland matrix is used mainly for pasture with a few isolated trees that provide shade for the cattle.

Tree layer survey and forest remnants

The tree layer of seven forest remnants was investigated. These remnants were chosen based on a satellite image of the São João river basin Environmental Protection Area and surroundings in an effort to include remnants of different sizes and isolation levels. Since medium-sized to small disturbed remnants predominate in the area, we selected those with less disturbance and/or a longer period of post-disturbance recovery. The degree of disturbance was defined according to the structural aspects of the remnant (e.g., stratification, canopy openness, edge structure, liana abundance, average tree diameter) and signs of logging and/or fire. Three medium-sized (24-63 ha) and four small (5 -11 ha) remnants were selected. Minimum distance between a remnant and its nearest neighbour (i.e, a measure of isolation), was $65 \mathrm{~m}$; maximum distance was $262 \mathrm{~m}$.

The flora was sampled in two transects, each $10 \mathrm{~m}$ wide and of different lengths depending on the size of the remnant, subdivided into $10 \times 25 \mathrm{~m}$ plots, in a north-south and east-west direction. The transect method was used in order to include the greatest degree of floristic-structural heterogeneity in each remnant, including edge and interior of the remnants. A transect in the largest remnant was not continuous because it was interrupted by steep rocky slope. Trees with Diameter at Breast Height $(\mathrm{DBH}) \geq 5 \mathrm{~cm}$ were tagged, height and diameter were measured, and vouchers were collected for identification. Dead trees still standing were recorded.

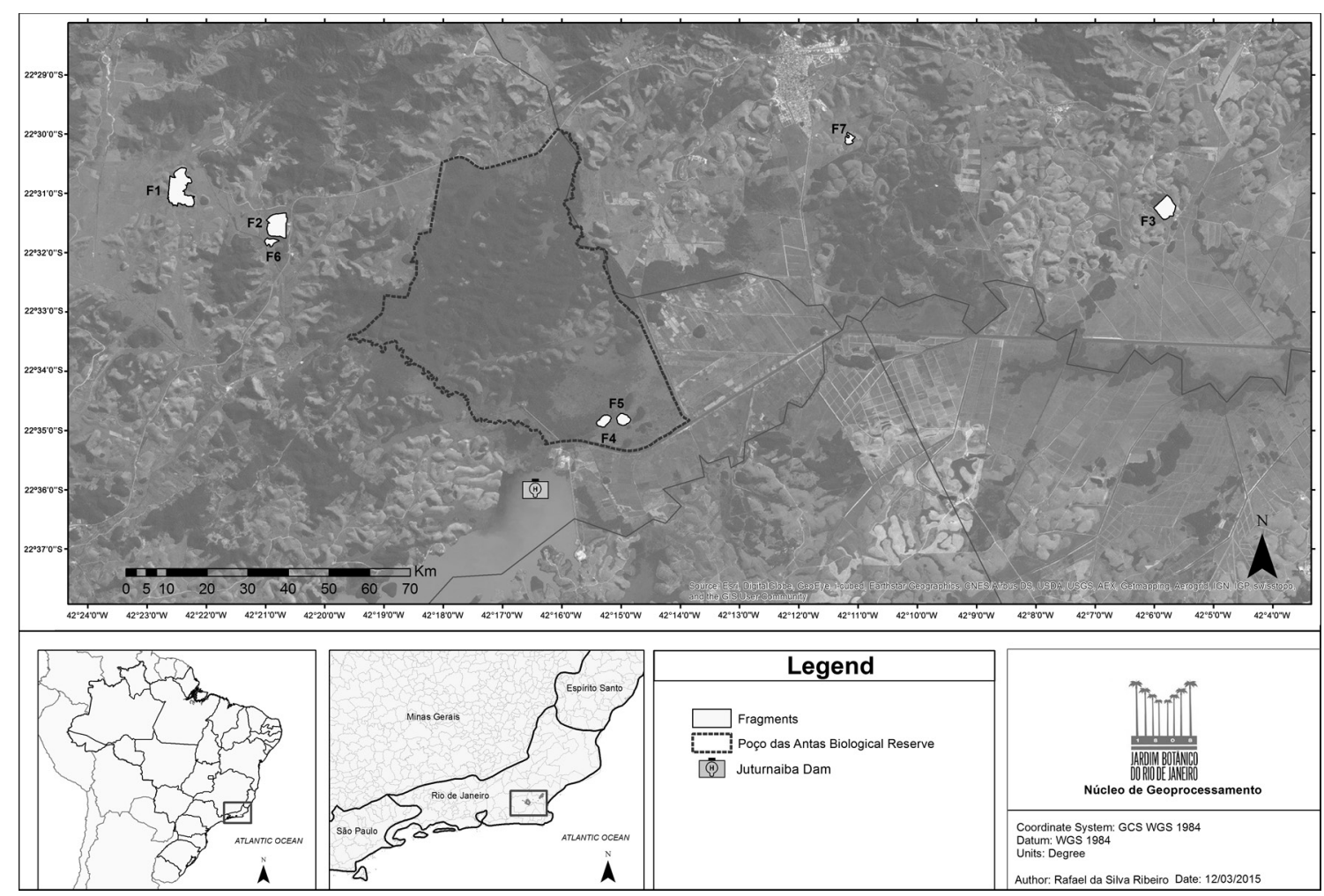

Figure 1 - Location of seven lowland forest remnants studied in the São João river basin, Rio de Janeiro, Brazil. F1 - Fazenda Santo Antonio do Maratuã; F2 and F6- Fazenda Santa Helena; F3 - Fazenda Carioca; F4 and F5 - Poço das Antas Biological Reserve; F7 - Fazenda do Trinta. 
Species were classified into one of two functional groups: early successional species (species capable of regenerating in open environments such as treefall gaps and new forest edges), and late successional species (species capable of regenerating in the shaded understorey of old growth forest). We assigned species into two basic categories of dispersal-syndrome: biotic (those typically associated with vertebrate dispersal agents) and abiotic (species dispersed by wind, gravity or explosive mechanisms). All species were assigned to the above categories using a comprehensive literature review (e.g., van der Pijl 1982; Gandolfi et al. 1995). The species were distributed in families according to APG IV (2016) and genera were placed in families based on Souza \& Lorenzi (2008). Plants were identified based on the botanical literature or consultation of specialists. Species names were updated according to Flora do Brasil 2020 [em construção]. Vouchers are deposited in the Rio de Janeiro Botanical Garden Herbarium (RB).

\section{Data analysis}

An individual-based species rarefaction curve was used to validate richness comparisons between the areas to correct possible distortions due to different size of sample areas (Gotelli \& Colwell 2001). In this analysis the curve is constructed based on the average number of species and number of individuals sampled. The individual-based rarefaction curve was constructed using Past (Hammer et al. 2001), consisting of species abundance data for a set of samples.

Non-metric multidimensional scaling - NMDS based on a matrix of presence/absence was used to analyze the floristic composition of the remnants using Bray-Curtis coefficient as a measure of similarity and to analyze correlations between floristic composition and three environmental variables: size, isolation and degree of disturbance. Multi-Response Permutation Procedures - MRPP (Quinn \& Keough 2002) was used to compare floristic composition between remnant groups, based on Euclidean distance. Two analyses were done: the first clustered remnants by size, forming two groups - medium-sized and small. The second analysis clustered remnants by disturbance level, forming three groups - low, intermediate and high. Analyses were done using PC-Ord (version 6.0. MjM Software, Gleneden Beach, Oregon). Two components were considered for the diversity analysis: $\alpha$-diversity - the diversity of a specific habitat or assemblage and $\beta$-diversity - between-habitat diversity (Magurran 2004).
Shannon's index and Fischer's $\alpha$ index (an index less sensitive to sample size) were used to calculate $\alpha$-diversity and Jaccard's similarity coefficient was used for $\beta$-diversity assessment (1- Jaccard's index). Since similarity refers to differences in species composition between localities, it can be seen as a measure of $\beta$-diversity. Therefore lower similarity between areas is associated with greater $\beta$-diversity (Magurran 2004).

Mantel's test was used to verify the influence of geographic distance between areas on the similarity index, using PC-Ord (version 6.0. MjM Software, Gleneden Beach, Oregon). The Spearman rank correlation coefficient (Zar 1996) was used to verify the relationship between remnant size and species richness, functional group and dispersal syndrome and, between isolation and species richness, functional group and dispersal syndrome.

\section{Results}

Floristic composition and remnant size

In the seven remnants, totaling 4.44 ha of sample area, 6101 plants were found belonging to 443 species, 60 families and 185 genera (Supplementary material in $<$ https://doi.org/10.6084/ m9.figshare.11327927.v1>). Within this area, the most species-rich families were Myrtaceae (62 species), Lauraceae (48), Fabaceae (42), Annonaceae (19), Sapotaceae (18) and Rubiaceae (17) (Tab. 1) representing $46 \%$ of all species sampled. The most diverse genera were Eugenia (21 species), Ocotea (20), Myrcia (10), Pouteria (8), Trichilia and Casearia (7) and Miconia and Erythroxylum (6). Ocotea and Eugenia were the most important genera in all remnants.

The 10 most important species in terms of number of plants per remnant were unevenly distributed both numerically and by sample area (Tab. 2). In fact, only 10 species (Mabea piriri Aubl., Astrocaryum aculeatissimum (Schott) Burret, Cupania racemosa (Vell.) Radlk., Casearia arborea (Rich.) Urb., Bathysa mendoncaei K.Schum., Helicostylis tomentosa (Poepp. \& Endl.) Rusby, Pogonophora schomburgkiana Miers ex Benth., Cabralea canjerana (Vell.) Mart., Siparuna reginae (Tul.) A.DC. and Aparisthimium cordatum (A.Juss.) Baill.) occurred in four or more remnants with 10 or more plants. The remnants showed a tendency to increase in the number of species and/or genera as total area increased. An exception was that of the F3 remnant, one of the most disturbed, where this tendency was not observed as regards family composition (Tab. 3). 
Table 1 - Families and genera of greater tree species richness in seven submontane forest remnants in the São João river basin, Rio de Janeiro, Brazil. $S=$ number of species; \% percentage of total richness.

\begin{tabular}{|c|c|c|}
\hline \multirow{2}{*}{$\begin{array}{l}\text { Local } \\
\text { Families }\end{array}$} & \multicolumn{2}{|c|}{ Total } \\
\hline & $S$ & $\%$ \\
\hline Myrtaceae & 62 & 14 \\
\hline Lauraceae & 48 & 10.8 \\
\hline Fabaceae & 42 & 9.5 \\
\hline Annonaceae & 19 & 4.3 \\
\hline Sapotaceae & 18 & 4.1 \\
\hline Rubiaceae & 17 & 3.8 \\
\hline Meliaceae & 12 & 2.7 \\
\hline Chrysobalanaceae & 11 & 2.5 \\
\hline Apocynaceae & 11 & 2.5 \\
\hline Sapindaceae & 10 & 2.3 \\
\hline Euphorbiaceae & 10 & 2.3 \\
\hline \multicolumn{3}{|l|}{ Genera } \\
\hline Eugenia & 21 & 4.7 \\
\hline Ocotea & 20 & 4.5 \\
\hline Myrcia & 10 & 1.6 \\
\hline Pouteria & 8 & 1.8 \\
\hline Trichilia & 7 & 1.6 \\
\hline Casearia & 7 & 1.6 \\
\hline Erythroxylum & 6 & 1.4 \\
\hline Miconia & 6 & 1.4 \\
\hline Annona & 5 & 1.1 \\
\hline Guatteria & 5 & 1.1 \\
\hline Maytenus & 5 & 1.1 \\
\hline Licania & 5 & 1.1 \\
\hline Inga & 5 & 1.1 \\
\hline Cryptocarya & 5 & 1.1 \\
\hline Calyptranthes & 5 & 1.1 \\
\hline Marlierea & 5 & 1.1 \\
\hline Psychotria & 5 & 1.1 \\
\hline
\end{tabular}

The individual-based species rarefaction curve showed that for the same number of plants (in this case the lower number of sampled individuals) a gradual increase in species number did not follow an increase in remnant size (Fig. 2). It also demonstrates that only the rarefaction curve of the F6 remnant does not fall within the $95 \%$ confidence interval of the others rarefaction curves at the sampling level chosen. That is, at this sampling level it differs significantly from the others in the number of species it supports.

Remnant attributes and variation in species richness and composition

Estimation of $\alpha$-diversity indicated areas of high species diversity, varying from $\mathrm{H}^{\prime}=3.68$ to $\mathrm{H}^{\prime}=4.40$ and $\alpha=34.86$ to $\alpha=75.69$ (Tab. 3). For $\beta$-diversity Jaccard's similarity index values were low, varying from 0.12 to 0.39 , and therefore leading to high $\beta$-diversity among the remnants. These results also highlight the dissimilarity between the F3 remnant and the others, as this consistently had the lowest values (Tab. 4). These results reflect considerable differentiation among the remnants as regards species composition. In fact, $46 \%$ of species were restricted to only one remnant, $12 \%$ occurred in only two and $22 \%$ were observed in four or more. Remnants F3 and F4 had the highest percentage of unique species, with $30 \%$ and $23 \%$ respectively.

The majority of the species recorded were late successional and biotic dispersal species $(55 \%$ and $79 \%$ ). Likewise, late successional and biotic dispersal species were more frequent in all remnants than early successional and abiotic dispersal species (Fig. 3). Only the two more disturbed remnants (F3 and F7) did not show a marked difference between the two functional groups.

The Mantel test, as applied to Jaccard similarity, indicated a positive correlation between geographic proximity and floristic similarity $(\mathrm{P}=0.002)$ of the remnants. The highest similarity values (ranging from $32 \%$ to $39 \%$ ) were obtained from areas up to $2 \mathrm{~km}$ apart, while the lower levels (ranging from $12 \%$ to $20 \%$ ) were observed in areas over $14 \mathrm{~km}$ apart.

The NMDS yielded the formation of two groups. The first group consisted of remnants F1, F2 and F6 and the second group was formed by remnants $\mathrm{F} 4$ and

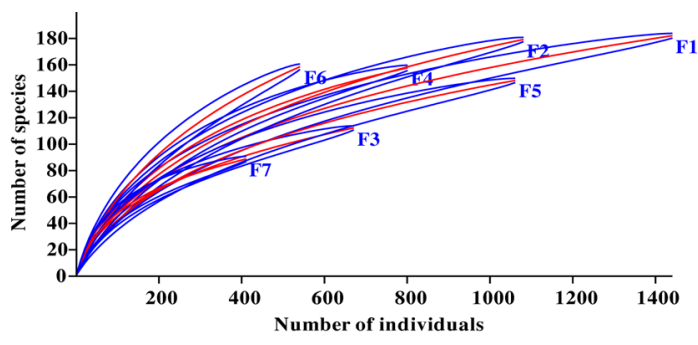

Figure 2 - Rarefaction curves and their 95\% confidence intervals for the number of tree species sampled in seven forest remnants in the São João River basin, Rio de Janeiro, Brazil. 


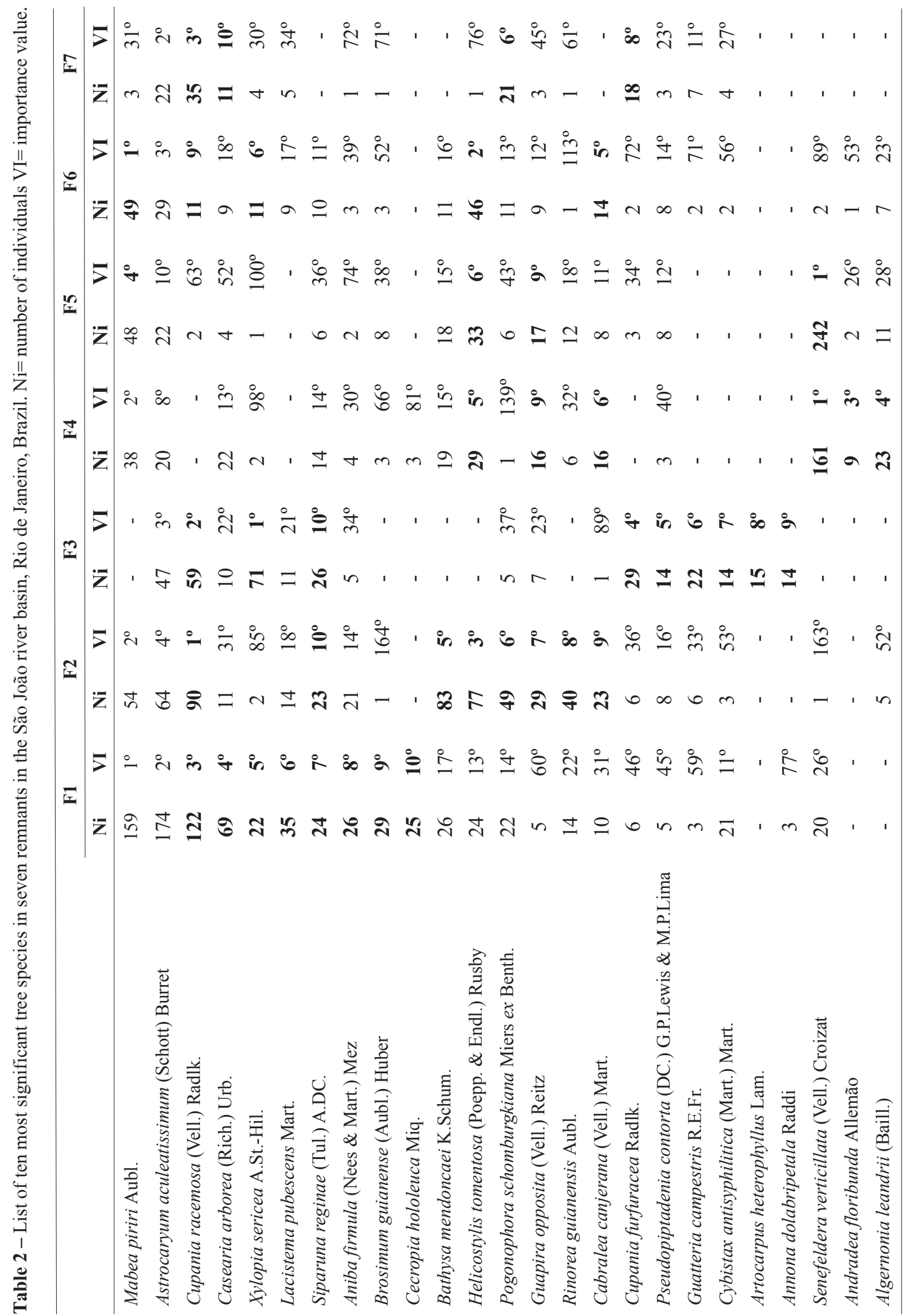




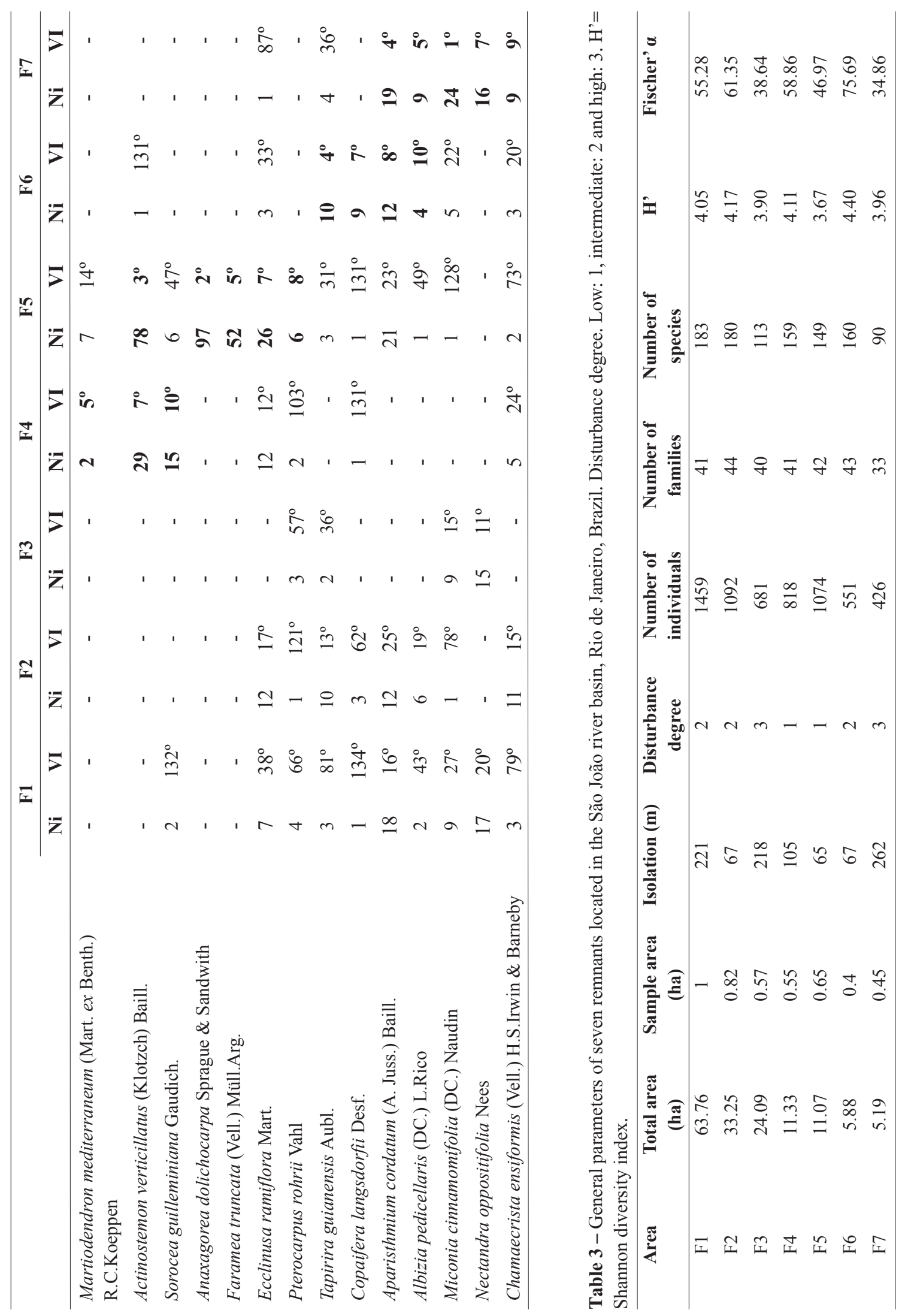


Table 4 - Floristic similarity between seven remnants located in the São João river basin, Rio de Janeiro, Brazil.

\begin{tabular}{lllllll}
\hline & F2 & F3 & F4 & F5 & F6 & F7 \\
\hline F1 & 0.399 & 0.176 & 0.239 & 0.269 & 0.318 & 0.235 \\
F2 & & 0.183 & 0.241 & 0.247 & 0.367 & 0.239 \\
F3 & & & 0.132 & 0.128 & 0.152 & 0.168 \\
F4 & & & & 0.358 & 0.241 & 0.131 \\
F5 & & & & & 0.273 & 0.173 \\
F6 & & & & & & 0.206 \\
\hline
\end{tabular}

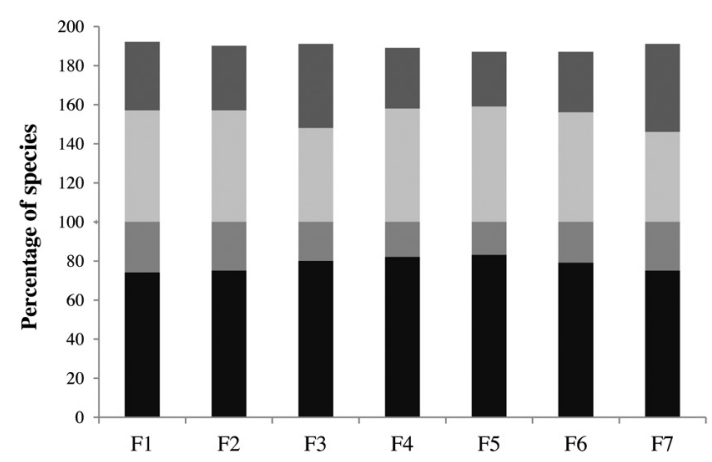

Figure 3 - Percentage of species by functional group and dispersal syndrome found in seven lowland forest remnants in the São João river basin, Rio de Janeiro, Brazil. Light black column, late successional; light gray column, early successional; dark gray column, biotic; dark black column, abiotic.

$\mathrm{F} 5$, while remnants $\mathrm{F} 3$ and $\mathrm{F} 7$ were outliers of these groups. The correlations were clearly discriminated on the diagram and the first and second axes explained $82.57 \%$ and $31.81 \%$, respectively, of the variation $\left(\mathrm{R}^{2}\right)$ (Fig. 4). The result revealed a separation between the remnants of high disturbance level (F7 and F3) positioned on the right side and the low (F4 and F5) and intermediate level (F1, F2 and F6) on the left of the diagram. It is also understood that the remnants of low

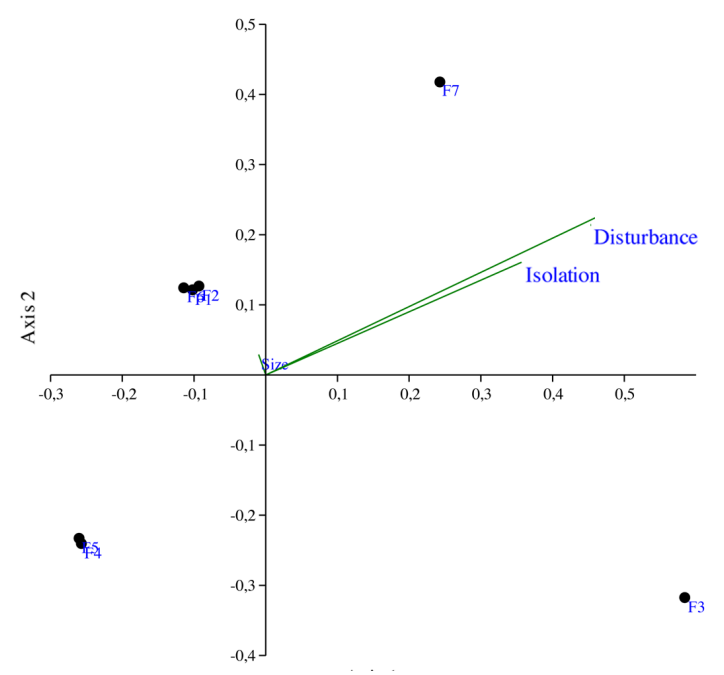

Figure 4 - Floristic relationships between seven lowland forest remnants in the São João river basin, Rio de Janeiro, Brazil produced by NMDS analysis and their correlation with three environmental variables used.

and intermediate level split, with the low level at the bottom and the intermediate level in the upper part of the diagram. Remnants F3 and F7 are linked to a higher level of disturbance and greater geographic distance.

In the analysis of floristic composition where remnants were clustered by size, the MRPP result indicated the absence of floristic differences $(\mathrm{A}=$ $0.006, \mathrm{P}=0.335$ ). However, the results obtained based on disturbance level showed significant differences in floristic composition between the remnants $(\mathrm{A}=0.088$, $\mathrm{P}=0.005)$. Analyses used to verify the relationship between remnant size and species richness and between remnant isolation and species richness did not support the hypotheses that higher species richness is related to greater remnant size $(\mathrm{R}=0.720, \mathrm{P}=$ 0.676 ) and lower species richness is related to greater remnant isolation $(R=-0.209, P=0.652)$. Species composition by functional group showed significant correlation with remnant size, but not with remnant isolation; remnant isolation or remnant size were not

Table 5 - Spearman correlation values between remnants and floristic composition parameters in seven submontane forest remnants in the São João river basin, Rio de Janeiro, Brazil.

\begin{tabular}{|c|c|c|c|c|c|c|c|c|c|c|}
\hline & \multicolumn{2}{|c|}{ Species richness } & \multicolumn{4}{|c|}{ Functional group } & \multicolumn{4}{|c|}{ Dispersal syndrome } \\
\hline & \multirow[b]{2}{*}{$\mathrm{R}$} & \multirow[b]{2}{*}{$\mathrm{p}$} & \multicolumn{2}{|c|}{ LS } & \multicolumn{2}{|c|}{ ES } & \multicolumn{2}{|c|}{$\mathrm{BIO}$} & \multicolumn{2}{|c|}{$\mathrm{ABIO}$} \\
\hline & & & $\mathrm{R}$ & $\mathrm{p}$ & $\mathrm{R}$ & $\mathrm{p}$ & $\mathrm{R}$ & $\mathrm{p}$ & $\mathrm{R}$ & $\mathrm{p}$ \\
\hline Remant size & 0.72 & 0.676 & 0.75 & 0.052 & 0.85 & 0.014 & 0.73 & 0.057 & 0.53 & 0.215 \\
\hline $\begin{array}{l}\text { Degrees of } \\
\text { isolation }\end{array}$ & -0.21 & 0.653 & -0.34 & 0.452 & 0.12 & 0.798 & -0.24 & 0.595 & -0.16 & 0.728 \\
\hline
\end{tabular}


significantly associated with species composition by dispersal syndrome (Tab. 5).

\section{Discussion}

Floristic composition and remnant size Species richness of the seven remnant groups (443 species) confirmed the high species richness of this region as mentioned by Carvalho et al. (2008). If we consider that fewer remnants were used in this study and that the individual-based species rarefaction curve slope did not stabilize, the results obtained here reinforce tree species richness in this region of the Atlantic Forest and suggest that factors others than sampling effort were influencing the results shown by the curve. Absence of trend towards stability is a very common result in tropical forests, where high species diversity makes it difficult to obtain a level of stability (Schilling \& Batista 2008).

In these areas, species richness of Myrtaceae, Lauraceae, Fabaceae, Sapotaceae, Euphorbiaceae, Annonaceae and Rubiaceae is striking and characterises the lowland forests on low hills in the central coastal lowlands of southeast Brazil (Sztutman \& Rodrigues 2002; Guedes-Bruni et al. 2006; Pessoa \& Oliveira 2006; Carvalho et al. 2008). Myrtaceae, Lauraceae and Fabaceae also stand out due to high species richness in lowland forests located between foothills of the mountains and the inner limits of coastal lowlands of Rio de Janeiro state (Kurtz \& Araujo 2000; Moreno et al. 2003). The richness pattern of these three families, as well as that of the genera Ocotea and Eugenia, reinforces patterns revealed for low-altitude forests of southeast Brazil (Oliveira-Filho \& Fontes 2000). Other families and genera in the study area were found in most of the studies mentioned above, suggesting that the composition of families and genera has floristic patterns similar to those observed in others forests of this formation.

Myrtaceae, Lauraceae and Fabaceae have been cited as related to a particular phase of recovery, degree of degradation, or reduced remnant size (Tabarelli et al. 1999; Tabarelli $\&$ Peres 2002). Similar results were obtained in this study, with fewer species of Myrtaceae and Lauraceae found in the more disturbed remnants and fewer Fabaceae species in smaller remnants. Since families, especially Lauraceae and Myrtaceae, constitute an important food source for frugivorous animals (Tabarelli \& Peres 2002; Lapenta et al. 2003) the changes observed may directly affect the abundance and persistence of the fauna and may negatively influence various ecological processes in these communities. It is noteworthy that the importance of Myrtaceae shows a close relationship with Atlantic coastal formations (Peixoto \& Gentry 1990; Sá \& Araujo 2009), while altitude seems to be the conditioning factor for Fabaceae with greater importance in low altitude forests (Ribeiro \& Lima 2009).

Inequalities found in species numbers by sampled area may be linked to the degree of disturbance and remnant size (Carvalho et al. 2006). In general, the results suggest a positive relationship between total area and number of species and/or genera, that is, larger areas have a greater number of species and genera (the wellknown species-area relationship).

Remnant attributes and variations on species richness and composition

Statistical analysis showed no significant difference between remnant size and floristic composition, as well as no relationship between species richness and size or isolation of the remnant. These results do not support assumptions of greater species richness with increased area and lower species richness with increased isolation. This enhances the factor disturbance, revealed at various levels in the remnants, as a strong influence in variation of composition and species richness of these remnants (Pessoa \& Araujo 2014), and also calls attention to the importance of interaction between factors. In fact, species composition by functional group and by dispersal syndrome revealed that the remnants still allow the presence of high proportion of large-seeded species associated with frugivores (Santos et al. 2008). Changes in the proportion of dispersal syndromes as a result of changes in assemblages and population density of frugivores, i.e. the availability of dispersal agents, have been related to fragmentation (Santos et al. 2008; Correa et al. 2015). Greater isolation does not necessarily mean species impoverishment if the remnant has environmental conditions and sufficient size to hold a larger number of species (Freitas et al. 2013). In fact, the data for remnant F1 suggest that, despite greater remoteness from nearest remnant, the size and intermediate disturbance status of this remnant currently allow for high species richness (Connell 1978).

The remnants showed high diversity of tree species with values very close to or slightly lower than those seen in lowland forests in southeast 
Brazil, in areas that are either disturbed $\left(\mathrm{H}^{\prime}=\right.$ 4.57) (Guedes-Bruni et al. 2006), regenerating $\left(H^{\prime}=3.78\right)($ Neves \& Peixoto 2008) or well preserved $\left(\mathrm{H}^{\prime}=4.02\right.$ to 4.06 ) (Kurtz \& Araujo 2000; Sztutman \& Rodrigues 2002). The data were not arranged according to a pattern of size or degree of disturbance, where the smallest and largest values belong to two small remnants (F5 and F6), the first being more disturbed than the second; two other disturbed remnants (F7 and F3) had higher values than remnant F5. Sample size may have a strong influence on the results (Magurran 2004), considering the small size of F6 with its greater diversity. On the other hand, F5 has an oligarchic structure, with a high percentage of species with low density (Pessoa \& Araujo 2014). Thus, lower diversity may reflect the dominance of a few species. On the other hand, the disturbance factor should not be discarded when assessing diversity per area. Disturbance, when promoting spatial and temporal heterogeneity, favors the coexistence of species with different demands for nutrients, light, temperature and humidity, and can also favor the dominance of certain species, therefore acting on composition and diversity of the community (Laurance et al. 2011). Thus, the initial hypothesis that diversity decreases with an increase in disturbance level was not supported, although the two more disturbed remnants showed low values. As mentioned above the abundance factor influenced the results.

Floristic differences between communities shown by the percentage of species unique to one locality $(46 \%)$ resulted in low similarity values, indicating high composition dissimilarity of tree species among remnants ( $\beta$-diversity). This result may possibly reflect various degrees of disturbance that remnants are undergoing, thus leading to high heterogeneity among samples (Pereira et al. 2007; Arroyo-Rodríguez et al. 2013). The influence of disturbance becomes more evident due to the greater proximity of values occurring according to degree of disturbance, also indicated by permutation analysis that showed significant differences in composition in relation to the level of disturbance. Therefore, remnants with similar disturbance levels show the most similar values, such as remnants F4 and F5.

Similarity relationships among remnants led to the formation of two groups. These are explained by level, history of disturbance and/ or geographic distance. As statistical analysis showed, the proximity and connectivity between areas influenced species turnover ( $\beta$-diversity) (Pereira et al. 2007; Carvalho et al. 2008; ArroyoRodríguez et al. 2013). Proximity and connectivity would facilitate exchange and dispersal of propagules between areas, i.e., closer areas with denser connections, would have a greater chance of success in events involving displacement of species and/or reproductive or genetic material transfer (Lopes \& Buzato 2007). Great geographic distance can restrict the interchange of species and propagules (Galanes \& Thomlinson 2009; Jesus et al. 2012). If this is associated with the defaunation process (Galetti et al. 2006) it may increase floristic differentiation among remnants. On the other hand, areas with a similar level and/or history of disturbance would show a proportionally greater possibility to have more similar environmental conditions and species with similar characteristics and ecological requirements, therefore increasing the chance of success for establishment and growth of arriving species. Since climate conditions and relief are considered to be similar for all remnants, these factors were not taken into consideration, although their contribution has already been indicated in group formations (Silva et al. 2008). For the remnant dealt with here, the factor level and/or history of disturbance seems to be acting strongly on dissimilarity in species composition, since both more-disturbed remnants constituted outliers of the two groups. The disturbance showed a negative impact on plant species diversity and acted as a factor of impoverishment of plant communities.

A variable that should not be neglected when working in fragmented landscapes is the habitat matrix (Nascimento et al. 2006; Biz et al. 2017). Except for F4, F5, F2 and F6 that have a narrow forest connection, the others are totally or partly surrounded by pastures. So, for the great majority of these remnants the matrix habitat has totally different physiognomy and floristic composition, which may or may not impede or make difficult biological flows and facilitate the entrance of exotics (Pires et al. 2002; Martensen et al. 2008; Santos et al. 2012).

Our study shows that contrary to what was expected, remnant size does not appear to be directly related to species diversity here, since the largest remnants were not necessarily the most diverse. Composition and diversity of species appear to be linked to various levels of disturbance imposed on these forests, and are therefore related to environmental characteristics and different 
regeneration phases of the forest. Despite the fact that size and isolation of the remnant did not show a significant relationship to tree-species richness, these results do not invalidate the influence of these factors on composition and richness. Since trees, on average, live for many years, many species may respond slowly to fragmentation, remaining several years at the site as adult individuals due to their longevity (Laurance et al. 2011). That is, time lags to changes in habitat configuration may be far more prolonged. The pattern found, where small fragments can support a large number of tree species, reinforces the fact that the fragment size may not be a limiting factor to species richness if the small fragments are linked structurally or functionally to neighbouring fragments, i.e., the matrix and spatial arrangement of the fragments allow biological flux along them (Biz et al. 2017). Linking the implications of our findings to conservation we can say that the limited coverage of protected areas has led to a growing interest in human-modified landscapes, where medium-sized or small remnants should be seen as important due to high floristic heterogeneity caused by environmental variation and disturbance suffered by these forests (Santos et al. 2007; ArroyoRodríguez et al. 2009; Joly et al. 2014). As shown here, medium-sized and small remnants ( $<100 \mathrm{ha})$ may prove essential to maintaining the diversity in human-modified landscapes, because they are capable of supporting a significant number of species, thus increasing the probability of survival of the regional species pool. These remnants have an important role as reservoirs of biodiversity, as well as in restoration initiatives in regions that have suffered extensive transformation. This is particularly the case of the Atlantic Forest where several regions have been converted to isolated medium-sized and small remnants.

\section{Acknowledgement}

We would like thank Adilson Pintor, Antonio Tavares and Jonas Dias for assistance in the field, the Poço das Antas Biological Reserve for logistical support at the field site, many taxonomist colleagues who helped us in the identification of botanical material, two anonymous reviewers for comments and the Petróleo Brasileiro (Petrobras, Brazilian Petroleum) for funding.

\section{References}

APG IV - The Angiosperm Phylogeny Group (2016) An update of the Angiosperm Phylogeny Group classification for the orders and families of flowering plants: APG IV. Botanical Journal of the Linnean Society 181: 1-20.

Arroyo-Rodríguez V, Pineda E, Escobar F \& BenítezMalvido J (2009) Value of small patches in the conservation of plant-species diversity in highly fragmented rainforest. Conservation Biology 23: 729-739.

Arroyo-Rodríguez V, Rös M, Escobar F, Melo FPL, Santos BA, Tabarelli M \& Chazdon R (2013) Plant $\beta$-diversity in fragmented rain forests: testing floristic homogenization and differentiation hypotheses. Journal of Ecology 101: 1449-1458.

Awade M \& Metzger JP (2008) Using gap crossing capacity to evaluate functional connectivity of two Atlantic rainforest birds and their response to fragmentation. Austral Ecology 33: 863-871.

Biz M, Cornelius C \& Metzger JPW (2017) Matrix type affects movement behavior of a Neotropical understory forest bird. Perspectives in ecology and conservation 15: 10-17.

Carvalho FA, Nascimento MT \& Braga JMA (2006) Composição e riqueza florística do componente arbóreo da Floresta Atlântica submontana na região de Imbaú, Município de Silva Jardim, RJ. Acta Botanica Brasilica 20: 727-740.

Carvalho FA, Nascimento MT \& Oliveira-Filho AT (2008) Composição, riqueza e heterogeneidade da flora arbórea da bacia do Rio São João, RJ, Brasil. Acta Botanica Brasilica 22: 929-940.

Connell JH (1978) Diversity in tropical rain forest and coral reefs. Science 199: 1302-1310.

Correa DF, Álvarez E \& Stevenson PR (2015) Plant dispersal systems in Neotropical forests: availability of dispersal agents or availability of resources for constructing zoochorous fruits? Global Ecology and Biogeography 24: 203-214.

Dale VH, King AW, Mann LK, Washington-Allen RA \& Mccord RA (1998) Assessing land-use impacts on natural resources. Environmental Management 22: 203-211.

Fahrig L (2003) Effects of habitat fragmentation on biodiversity. Annual Review of Ecology, Evolution and Systematics 34: 487-515.

Flora do Brasil 2020. Jardim Botânico do Rio de Janeiro. Available at <http://floradobrasil.jbrj.gov.br/. Access in August 2017.

Freitas CG, Dambros C \& Camargo JLC (2013) Changes in seed rain across Atlantic Forest fragments in Northeast Brazil. Acta Oecologica 53: 49-55.

Galanes IT \& Thomlinson JR (2009) Relationships between spatial configuration of tropical forest patches and woody plant diversity in northeastern Puerto Rico. Plant Ecology 201: 101-113.

Galetti M, Donatti CI, Pires AS, Guimarães JRPR \& Jordano P (2006) Seed survival and dispersal of an endemic Atlantic forest palm: the combined effects 
of defaunation and forest fragmentation. Botanical Journal of Linnean Society 151: 41-150.

Gandolfi S, Leitão Filho HF \& Bezerra CLF (1995) Levantamento florístico e caráter sucessional das espécies arbustivo-arbóreas de uma floresta mesófila semidecídua no município de Garulhos, SP. Revista Brasileira de Biologia 55: 753-767.

Gotelli NJ, Colwell RK (2001) Quantifying biodiversity: procedures and pitfalls in the measurement and comparison of species richness. Ecology Letters 4: 379-391.

Guedes-Bruni RR, Neto SJS, Morim MP \& Mantovani W (2006) Composição florística e estrutura de dossel em trecho de floresta ombrófila densa atlântica sobre morrote mamelonar na Reserva Biológica de Poço das Antas, Silva Jardim, Rio de Janeiro, Brasil. Rodriguésia 57: 429-442.

Haila Y (2002) A conceptual genealogy of fragmentation research: from island biogeography to landscape ecology. Ecological Application 12: 321-334.

Hammer Ø, Harper DAT \& Ryan PD (2001) PAST: Paleontological statistics software package for education and data analysis. Palaeontologia Electronica 4: 9. Available at $<$ http://palaeoelectronica.org/2001_1/past/issue1_01.htm $>$ Access in May 2017.

Jesus FM, Pivello VR, Meirelles ST, Franco GADC \& Metzger JP (2012) The importance of landscape structure for seed dispersal in rain forest fragments. Journal of Vegetation Science 23: 1126-1136.

Joly CA, Metzger JP \& Tabarelli M (2014) Experiences from the Brazilian Atlantic Forest: ecological findings and conservation initiatives. New Phytologist 204: 459-473.

Kurtz BC \& Araujo DSD (2000) Composição florística e estrutura do componente arbóreo do um trecho de Mata Atlântica na Estação Ecológica Estadual do Paraíso, Cachoeiras de Macacu, Rio de Janeiro, Brasil. Rodriguésia 51: 69-112.

Lapenta MJ, Procópio de Oliveira P, Kierluff MCM \& Mota-Junior JC (2003) Fruit exploitation by golden lion tamarins (Leontopithecus rosalia) in the União Biological Reserve, Rio das Ostras, RJ - Brazil. Mammalia 67: 41-46.

Laurance WF, Camargo JLC, Luizão RCC, Laurance SG, Pimm SL, Bruna EM, Stouffer PC, Williamson GB, Benítez-Malvido J, Vasconcelos HL, Van Houtan KS, Zartman CE, Boyle SA, Didham RK, Andrade A \& Lovejoy TE (2011) The fate of Amazonian forest fragments: a 32-year investigation. Biological Conservation 144: 56-67.

Lôbo D, Leão T, Melo FPL, Santos AMM \& Tabarelli M (2011) Forest fragmentation drives Atlantic Forest of northeastern Brazil to biotic homogenization. Diversity and Distributions 17: 287-296.

Lopes LE \& Buzato S (2007) Variation in pollinator assemblages in a fragmented landscape and its effects on reproductive stages of a self-incompatible treelet, Psychotria suterella (Rubiaceae). Oecologia 154: 305-314.

Magurran AE (2004) Measuring biological diversity. Blackwell Science Ltd, Oxford. 256p.

Martensen AC, Pimentel RG \& Metzger J.P (2008) Relative effects of fragment size and connectivity on bird community in the Atlantic Rain Forest: implications for conservation. Biological Conservation 141: 2184-2192.

Moreno MR, Nascimento MT \& Kurtz BC (2003) Estrutura e composição florística do estrato arbóreo em duas zonas altitudinais na Mata Atlântica da região do Imbé, RJ. Acta Botanica Brasilica 17: 371-386.

Murcia C (1995) Edge effects in fragmented forests: implications for conservation. Trends in Ecology and Evolution 10: 58-62.

Nascimento HEM, Andrade ACS, Camargo JLC, Laurance WF, Laurance SG \& Ribeiro JEL (2006) Effects of the surrounding matrix on the recruitment in Amazonian forest fragments. Conservation Biology 20: 853-860.

Neves GMS \& Peixoto AL (2008) Florística e estrutura da comunidade arbustivo-arbórea de dois remanescentes em regeneração de Floresta Atlântica secundária na Reserva Biológica de Poço das Antas, Silva Jardim, Rio de Janeiro. Pesquisas Botânica 59: 71-112.

Oliveira-Filho AT \& Fontes MAL (2000) Patterns of floristic differentiation among atlantic forests in southeastern Brazil and the influence of climate. Biotropica 32: 793-810.

Oliveira MA, Santos AMM \& Tabarelli M (2008) Profound impoverishment of the large-tree stand in a hyper-fragmented landscape of the Atlantic forest. Forest Ecology and Management 256: 1910-1917.

Peixoto AL \& Gentry A(1990) Diversidade e composição florística da mata de tabuleiro na Reserva Florestal de Linhares (Espírito Santo, Brasil). Revista Brasileira de Botânica 13: 19-25.

Pereira JAA, Oliveira-Filho AT \& Lemos-Filho JP (2007) Enviromental heterogeneity and disturbance by humans control much of the tree species diversity of Atlantic montane forest fragments in SE Brazil. Biodiversity and Conservation 16: 1761-1784.

Pessoa SVA \& Oliveira RR (2006) Análise estrutural da vegetação arbórea em três fragmentos florestais na Reserva Biológica Poço das Antas, Rio de Janeiro, Brasil. Rodriguésia 57: 391-411.

Pessoa SVA \& Araujo DSD (2014) Tree community dynamics in a submontane forest in southeastern Brazil: growth, recruitment, mortality and changes in species composition over a seven-year period. Acta Botanica Brasilica 28: 190-197.

Pires AS, Lira PK, Fernandez FAS, Schittini GM \& Oliveira LC (2002) Frequency of movements of small mammals among Atlantic Coastal Forest 
fragments in Brazil. Biological Conservation 108: 229-237.

Quinn GP \& Keough M J (2002) Experimental design and data analysis for biologists. Cambridge University Press, New York. 537p.

Ribeiro RD \& Lima HC (2009) Riqueza e distribuição geográfica de espécies arbóreas da família Leguminosae e implicações para conservação no Centro de Diversidade Vegetal de Cabo Frio, Rio de Janeiro, Brasil. Rodriguésia 60: 111-127.

Sá CFC \& Araujo DSD (2009) Estrutura e florística de uma floresta de restinga em Ipitingas, Saquarema, Rio de Janeiro, Brasil. Rodriguésia 60: 147-170.

Santos BS, Peres CA, Oliveira MA, Grillo A, AlvesCosta CP \& Tabarelli M (2008) Drastic erosion in functional attributes of tree assemblages in Atlantic forest fragments of northeastern Brazil. Biological Conservation 141: 249-260.

Santos K, Kinoshita LS \& Santos FAM (2007) Tree species composition and similarity in semideciduous forest fragments of southeastern Brazil. Biological Conservation 135: 268-277.

Santos GGA, Santos BA, Nascimento HEM \& Tabarelli M (2012) Contrasting demographic structure of short- and long-lived pioneer tree species on Amazonian forest edges. Biotropica 44: 771-778.

Schilling AC \& Batista JLF (2008) Curva de acumulação de espécies e suficiência amostral em florestas tropicais. Revista Brasileira de Botânica 31: 179-187.

Silva JMC \& Tabarelli M (2000) Tree species impoverishment and the future flora of the Atlantic Forest of northeast Brazil. Nature 404: 72-74.
Silva SSL, Zickel CS \& Cestaro LA (2008) Flora vascular e perfil fisionômico de uma restinga no litoral sul de Pernambuco, Brasil. Acta Botanica Brasilica 22: 1123-1135.

Souza VC \& Lorenzi H (2008) Botânica sistemática guia ilustrado para identificação das famílias de Fanerógamas nativas e exóticas no Brasil, baseado em APG II. Instituto Plantarum, Nova Odessa. $703 p$.

Sztutman M \& Rodrigues RR (2002) O mosaico vegetacional numa área de floresta contínua da planície litorânea, Parque Estadual da Campina do Encantado, Pariquera-Açu, SP. Revista Brasileira de Botânica 25: 161-176.

Tabarelli M, Mantovani W \& Peres CA (1999) Effects of habitat fragmentation on plant guild structure in the montane Atlantic forest of southeastern Brazil. Biological Conservation 91: 119-127.

Tabarelli M \& Peres CA (2002) Abiotic and vertebrate seed dispersal in the Brazilian Atlantic forest: implications for forest regeneration. Biological Conservation 106: 165-176.

Tabarelli M \& Lopes AV (2008) Edge-effects drive tropical forest fragments towards an earlysuccessional system. Biotropica 40: 657-661.

van der Pijl L (1982) Principles of dispersal in higher plants. Springer-Verlag, Berlin. 214p.

Veloso HP, Rangel Filho ALR \& Lima JCA (1991) Classificação da vegetação brasileira adaptada a um sistema universal. IBGE, Rio de Janeiro. 124p.

Zar JH (1996) Biostatistical analyses. $4^{\text {th }}$ ed. Prentice Hall, New Jersey. 929p. 